\title{
A intervenção da sociedade civil no sistema prisional em Moçambique
} Marcio Américo Vieira Pessôa1

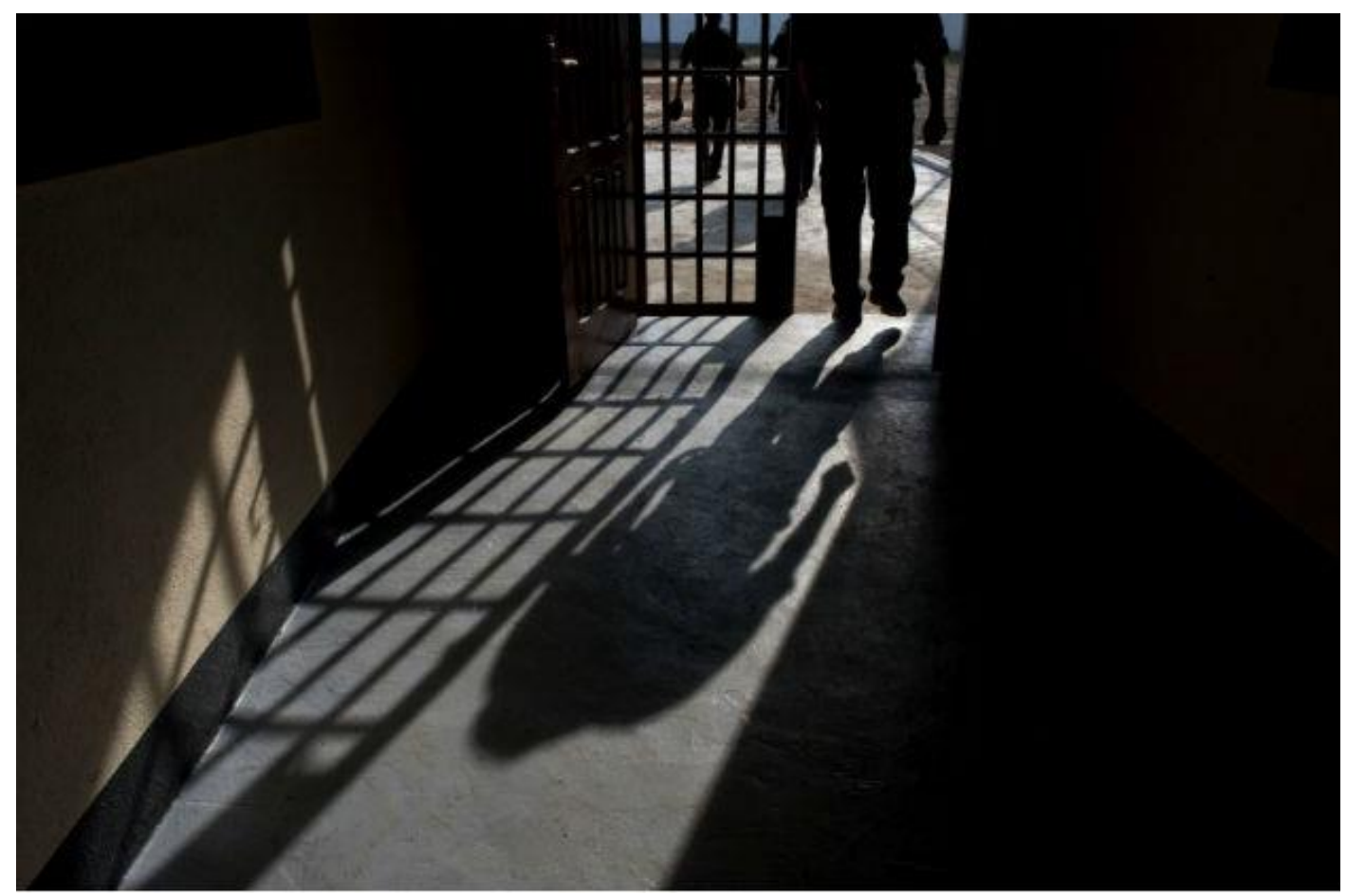

RESUMO: Este artigo examina o papel da Liga Moçambicana dos Direitos Humanos (LDH) na transformação do sistema prisional de Moçambique. A pergunta ampla é: até que ponto a vigilância da sociedade civil aos direitos humanos no sistema prisional moçambicano reflete com profundidade às necessidades da massa carcerária? A análise é fruto pesquisa de campo de dez meses entre 2013 e 2015, nos quais, através de revisão bibliográfica e observação participativa, foi acompanhado o trabalho da LDH nas cadeias. Explora-se aqui a teoria do desacato na sociedade civil (defiance in civil society), que contribui para a leitura contextual do esforço de organizações e indivíduos para abrir espaços de participação a fim de fazer com que questões reais para grupos sociais tornem-se políticas públicas. Conclui-se que a abordagem sob o ponto de vista dos direitos humanos gerou transformações positivas desde os anos 1990, mas não foi capaz de impulsionar políticas públicas sustentáveis para o setor.

PALAVRAS-CHAVE: África; sociedade civil; Moçambique; políticas públicas; participação.

\footnotetext{
${ }^{1} \mathrm{PhD}$ em Estudos do Desenvolvimento - Institute of Development Studies University of Sussex. E-mail:m.pessoa@ids.ac.uk
} 


\section{INTRODUÇÃO}

Este artigo tem como objetivo aprofundar o entendimento sobre questões reais e periféricas, indicando que é possível trabalhá-las estrategicamente durante contestações da sociedade civil a regimes que restringem espaços de participação democrática. O caso da intervenção da Liga dos Direitos Humanos (LDH) no sistema prisional mostra que o ativismo pode abandonar o desacato ao regime autoritário e optar por um processo de construção compartilhada (ou co-construção), mas há fatores naturais de um sistema disfuncional em termos de participação que obstaculizam que as demandas se transformem em políticas públicas. A análise demonstra que o processo de contestação e advocacia da LDH se ateve a questões normativas, sem que se tenha feito uma abordagem mais profunda e adotado estratégias para trazer à tona questões consideradas cruciais da população carcerária. Assim, cabe a pergunta ampla: até que ponto a vigilância da sociedade civil aos direitos humanos no sistema prisional moçambicano reflete com profundidade às necessidades da população carcerária? Explora-se aqui a teoria do desacato na sociedade civil (ou defiance in civil society), que contribui para a leitura contextual do esforço de organizações e indivíduos para abrir espaços de participação a fim de fazer com que questões reais para indivíduos se tornem políticas públicas.

Inicialmente, apresenta-se uma breve noção histórica sobre o engajamento da Liga na questão prisional desde sua fundação após a guerra dos 16 anos até o início de sua crise institucional em 2014. Após, observa-se momentos de resistência do Estado para a elaboração de reformas e o momento em que a ONG abandona a contestação à base de questões reais para se dedicar à normativo-periféricas. Por último, reflete-se sobre os efeitos da normatividade dos direitos humanos na garantia das necessidades vitais da população carcerária no cumprimento de sua pena. Este trabalho é fruto de uma revisão bibliográfica acompanhada por consulta de relatórios de organizações e institutos de direitos humanos, além de entrevistas durante pesquisa de campo realizada entre 2013 e 2015 com observação participativa na Liga dos Direitos Humanos e no Centro de Direitos Humanos da Universidade Eduardo Mondlane.

\section{A LDH E A TRANSFORMAÇÃO DO SISTEMA PRISIONAL}

A Liga foi fundada em 1993, numa época em que se começou a debater sobre direitos humanos em Moçambique. Poucos anos antes do surgimento da ONG, vigoravam penas como fuzilamento, castigos corporais, trabalho e deslocamento forçado de pessoas consideradas "improdutivas" pelo regime. ${ }^{2}$ Nos anos 1990, relatórios de organizações internacionais denunciavam prisões preventivas expiradas, superlotação, falta de comida e assistência médica nas

\footnotetext{
${ }^{2}$ A constituição de 1990 aboliu a pena de morte. De 1979 a 1990, os moçambicanos conviveram com fuzilamentos determinados pelo Tribunal Militar Revolucionário Um dos integrantes de tal tribunal foi reconduzido à presidência do Conselho Constitucional de Moçambique em julho de 2016 (Verdade 2016, CRM 2004).
} 


\section{$\sum_{0}^{\frac{\pi}{0}} 0$ \\ Revista África e Africanidades - Ano XIII - n. 34, maio. 2020 - ISSN 1983-2354 \\ www.africaeafricanidades.com.br}

penitenciárias. Detentos denunciavam reiteradamente espancamentos, estupros, assassinatos e extorsões para visitas, libertação e comida. ${ }^{3}$ Mesmo ao longo dos anos 2000, os obstáculos para o cumprimento de penas com dignidade eram imensos porque o Estado moçambicano incluía direitos humanos timidamente na sua agenda. 4 "Era comum ver reclusos com sarna, magérrimas, empilhados em selas, revezando horas de sono, sem saneamento e sem direito a banho de sol. Acompanhei os integrantes da Comissão Africana de Direitos Humanos chorarem ao visitarem prisões em Moçambique", diz um trabalhador da Liga. ${ }^{5}$

A LDH ajudou a abrir os estabelecimentos prisionais aos olhos da sociedade através do monitoramento de 11 cadeias provinciais, inúmeras prisões distritais e de unidades policiais - as chamadas cadeias das esquadras. Após a Constituição de 1990, a Liga adotou um tom de confrontação ao comportamento do Estado em relação a massa carcerária. Havia outras organizações cívicas, religiosas e profissionais que atuavam em questões onde o Estado era violador dos direitos humanos, mas o tom audacioso e desafiante de confrontação normativa baseada nos direitos humanos fez a ONG liderar o debate sobre as condições do sistema prisional moçambicano. ${ }^{6}$ A Liga ganhou notoriedade e amadureceu um repertório contencioso ${ }^{7}$ baseado em declarações em eventos de embaixadas, de outras organizações da sociedade civil e da academia, além da publicação de relatórios e aparições na imprensa.

O desacato na sociedade civil é um processo de conflito que coloca indivíduos, grupos formais e/ou informais de um lado e estruturas poderosas do outro, e é marcado por ações violentas e/ou não-violentas, resiliência, vigilância, foco, audácia e força. O desacato nas disputas de poder da sociedade civil parece ignorar a formação de alianças; pode ser audacioso e vigoroso sem ser duradouro. Pode levar à neutralização, construção conjunta (ou co-construção) ou mudanças reais (ver Fig.3.1). O processo de desacato pode ou não ser liderado por movimentos sociais, mas é visível em ambientes de contestação. ${ }^{8}$ No caso da Liga, apesar de não promover ações violentas ou não-violentas aliadas com grupos de familiares de detentos para início de um processo de desacato ao sistema prisional, como protestos em frente às cadeias ou em locais públicos, a liga fez uma intervenção no sistema prestando assistência jurídica a dezenas de milhares de detentos ao longo dos anos. Não havia uma polarização

\footnotetext{
${ }^{3}$ Ver HRW 1996, 1998, 2000.

${ }^{4}$ Entrevista Trabalhador de ONG, Maputo, 30 de outubro de 2016; HRW 1996, 1998, 2000.

${ }^{5}$ Entrevista Trabalhador de ONG, Maputo, 4 de dezembro de 2014

6 HRW 1997, 1998, 2000; Entrevista Trabalhador de ONG, Maputo, 24 November 2014; Entrevista Trabalhador de ONG, Maputo, 30 De outubro de 2016; Entrevista Trabalhador de ONG, Maputo, 4 de dezembro de2014; HRW relatórios (2000), por exemplo, diz que, no final da década de 1990, a Associação de Direitos Humanos e Desenvolvimento (DHD) pediu uma "ação conjunta" entre o governo e a sociedade civil para focar na verificação do abuso de poder nas prisões, suborno em instituições públicas, abusos sexuais e casamentos forçados.
}

7 Ver Tilly and Tarrow (2015)

8 Pessôa, 2018, p.20 


\section{要0 \\ Revista África e Africanidades - Ano XIII - n. 34, maio. 2020 - ISSN 1983-2354 \\ www.africaeafricanidades.com.br}

clara com o governo porque a Liga precisava manter uma relação minimamente amistosa com as autoridades prisionais para conseguir acesso às prisões e que sua voz fosse ouvida pelo governo. Por sua vez, o governo não reconhecia que violava os direitos humanos e cedia muito mais a pressão internacional do que a pressão da sociedade civil moçambicana.

Fig.1 Latência, processos de desacato e co-construção.

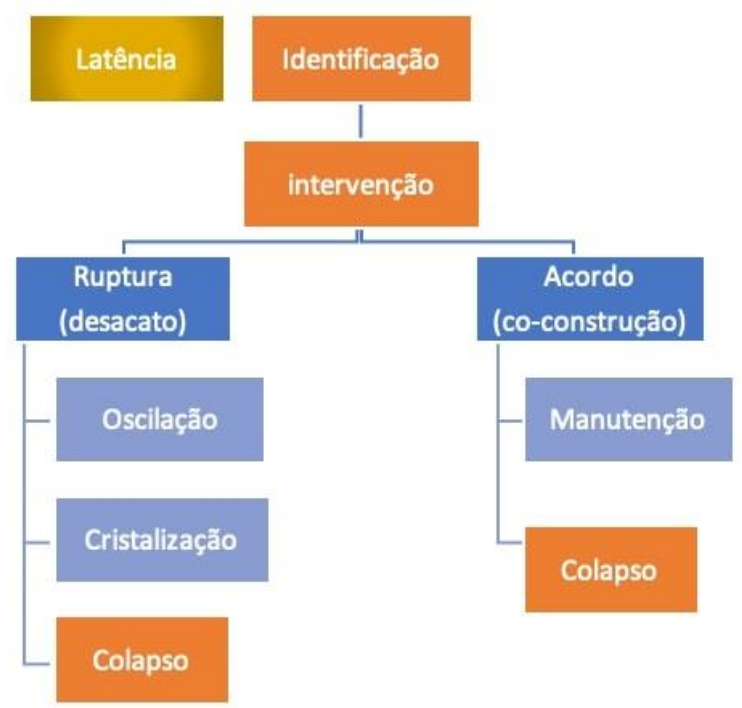

Até 2009, a sociedade civil não tinha livre acesso às prisões. A LDH dava cronogramas de inspeções às autoridades, informando quem participaria, o local e a data. Mesmo assim, muitas vezes, era impedida de cumpri-los. ${ }^{9}$ Aos poucos, a Liga constituiu unidades nas províncias que compartilhavam informações, denunciando casos de violação de direitos à mídia. Ao longo dos anos 2000, publicou edições do Relatório Anual dos Direitos Humanos, um dos seus principais produtos, que continha análise de juristas e paralegais sobre a situação do sistema prisional e práticas dos agentes de segurança pública. "Às vezes sentia medo por tudo que denunciávamos na TV, mas tínhamos uma grande líder, que se mostrava destemida e nos dava confiança", diz um exfuncionário sobre a única presidente que a ONG teve em seus 25 anos. ${ }^{10}$ Neste processo, a LDH solidificou a sua credibilidade nacional e internacionalmente, com seus relatórios servindo de base para a avaliação dos direitos humanos em Moçambique por várias organizações e órgãos de países ocidentais. ${ }^{11}$

A LDH ficou muitos anos num estágio de intervenção (ver Fig. 2.1), ou seja, um padrão marcado pelo "movimento" que leva questões à esfera pública e cimenta uma ambiente de contestação. ${ }^{12}$ Para serem capazes de passar da fase de intervenção para a construção compartilhada (ou co-construção), porém,

\footnotetext{
${ }^{9}$ Entrevista Trabalhador de ONG, Maputo, 30 de outubro de 2016; Trabalhador de ONG, Maputo, 4 de dezembro de 2014

10 Entrevista Trabalhador de ONG, Maputo, 4 de dezembro de2014

${ }^{11}$ Entrevista Trabalhador de ONG, Maputo, 30 de outubro de 2016; relatórios da HRW (1997, 1998, 2000); Lorizzo (2012); ver U.S.D.S (2010)

12 Ver Lang (2013) e Habermas (1992)
} 


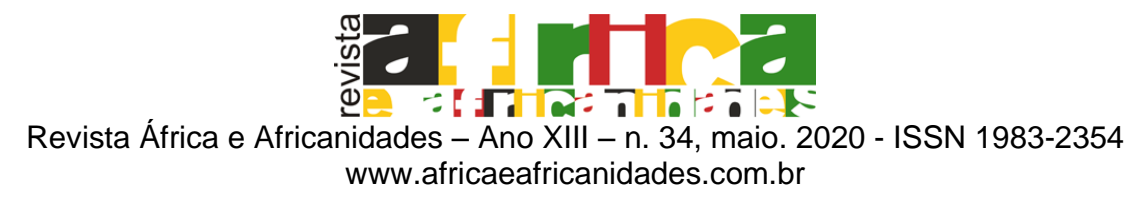

sociedade civil e Estado precisam reconhecer a disputa, entrar num acordo de diálogo, e avançar para as próximas etapas rumo a uma política pública, abordando questões através da ação coletiva. Se em vez de acordo houver uma polarização declarada entre os mais poderosos e os desafiantes, configura-se um cenário de desacato. O padrão de intervenção mostrou resultados: o governo moçambicano - que nos anos 1990 e início dos anos 2000 não "fazia referência aos direitos humanos em seus relatórios" - passou a chamar técnicos da Liga para audiências bilaterais e para responder denúncias da organização. ${ }^{13}$ "Se antes as autoridades ignoravam o tema achando que era uma estratégia das organizações para angariar fundos, a partir das ações da Liga, começaram a cooperar". ${ }^{14}$ Ou seja, Liga e governo iniciaram uma transição de relação que se concretizou nos anos seguintes.

Em 2008, Benvinda Levy assumiu a pasta do Ministério da Justiça com o compromisso de abrir as portas das prisões para a mídia, academia e sociedade civil. Essa política teve como marco a assinatura do memorando de entendimento com a Liga, em 2009, que estabeleceu acordos de obrigações mútuas com o Ministério da Justiça e engajamento no Programm for stregthening national capacity and support to legal reform in the prison sector for sustainable implemetnation, do PNUD. ${ }^{15} \mathrm{O}$ governo deu à organização acesso às cadeias e reconheceu sua expertise sobre o tema. No início do segundo mandato de Armando Guebuza, a constelação de questões em aberto há mais de 15 anos empurrava um processo de construção compartilhada entre Estado e sociedade civil. Os acordos estabeleciam que a Liga faria recomendações e o governo teria um prazo para cumpri-las. Caso não resolvesse a questão, a LDH poderia denunciá-la à imprensa e até em âmbito internacional. ${ }^{16}$ Inaugurava-se um canal permanente de diálogo entre Estado e sociedade civil, onde o governo respondia e justificava porque eventualmente não conseguia cumprir as recomendações. ${ }^{17}$ Selava-se a construção compartilhada sobre o sistema prisional, um fenômeno que aumentou em 11 vezes o orçamento para o setor em quatro anos (ver gráfico 7).

Fig. 2 Evolução do orçamento dos serviços prisionais durante a construção compartilhada (MT)

\footnotetext{
${ }^{13}$ Entrevista Trabalhador de ONG, Maputo, 30 de outubro de 2016

${ }^{14}$ Entrevista Trabalhador de ONG, Maputo, 30 de outubro de 2016

15 Ver U.S.D.S (2010); ODAMOZ (2011) - todos os links das referências estão na bibliografia.

${ }^{16}$ Entrevista Trabalhador de ONG, Maputo, 30 de outubro de 2016

17 Entrevista Trabalhador de ONG, Maputo, 4 de dezembro de2014; Entrevista Trabalhador de ONG, Maputo, 30 de outubro de 2016
} 


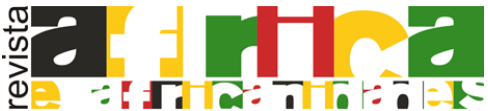

Revista África e Africanidades - Ano XIII - n. 34, maio. 2020 - ISSN 1983-2354 www.africaeafricanidades.com.br

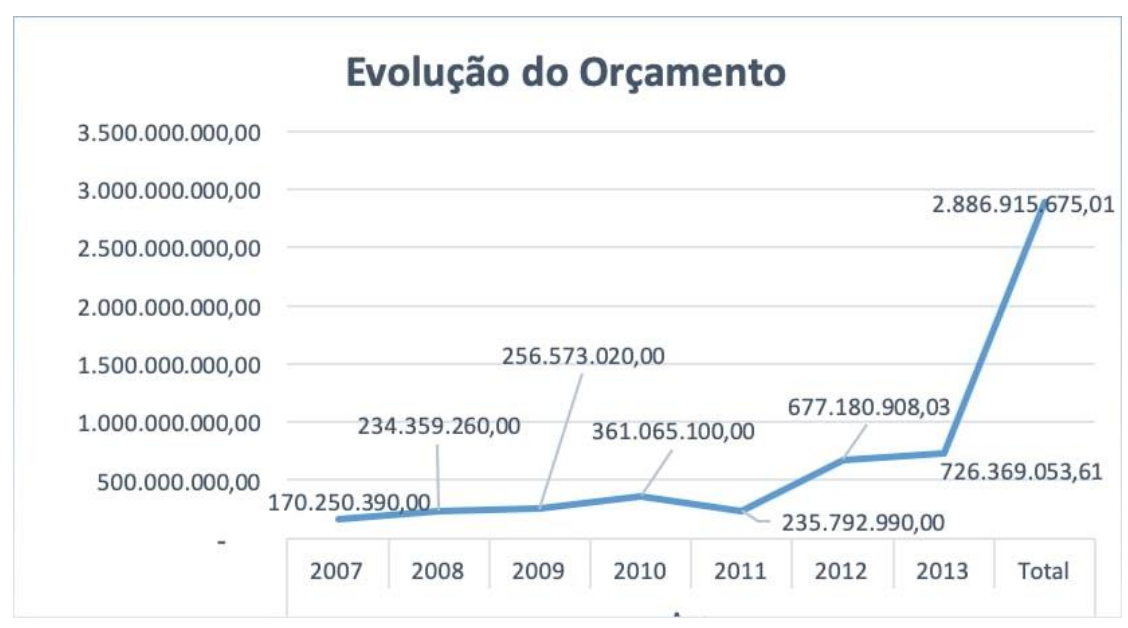

FONTE: CDH e LDH, 2015

Moçambique permanece com carências nas penitenciarias, frutos de questões amplas na gestão estatal da justiça. Por exemplo, a superlotação não está somente relacionada ao número de unidades prisionais (ver tabela 11), mas também ao número de prisões preventivas expiradas, prisões arbitrárias e falta de penas alternativas. ${ }^{18}$ Dados do Serviço Nacional Penitenciário (SERNAP) divulgados para a imprensa dão conta de que, em 2017, o sistema tinha capacidade para 8,2 mil vagas, mas o total de presos chegava a 11,8 mil, e 6,2 mil reclusos estão em prisão preventiva. ${ }^{19}$ Até 2014, a LDH denunciou casos de tratamentos degradantes em custodia e registrou em média um caso de tortura a cada dez dias, e o monitoramento detalhado das esquadras era um desafio. ${ }^{20}$

Mesmo neste cenário complexo, após 20 anos, "o velho mundo militarista e secretista das prisões foi aberto para a o público e para a pesquisa acadêmica". ${ }^{21}$ As mudanças são nítidas não somente nas instalações, mas na conscientização de quem trabalha no setor. ${ }^{22}$ Estes são os resultados do processo de construção compartilhada, citados por alguns trabalhadores da Liga:

'Nós conseguimos o que muitos países africanos não conseguiram: a atenção aos direitos humanos nas prisões. A consciência dos próprios guardas prisionais mudou. Antes, eles nos viam como inimigos do governo e fechavam tudo. Tentavam limpar pistas. Por isto que tínhamos que anunciar as nossas visitas previamente. Mas agora o próprio Ministério da Justiça e a LDH têm memorando de entendimento'.23

Portanto, a Liga colaborou para mudanças importantes de comportamento ficando 15 anos num padrão de intervenção. Neste período, não

\footnotetext{
18 Ver CDH e LDH (2015)

19 Diário de Notícias (2017)

20 Ver Pessôa et al. (2014)

${ }^{21}$ Lorizzo, 2012, p.36

22 DW África (2014).

${ }^{23}$ Entrevista Trabalhador de ONG, Maputo, 4 de dezembro de2014
} 


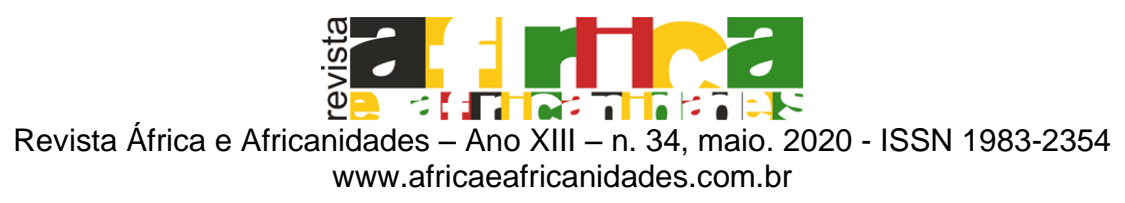

avançou para processos de desacato ou construção compartilhada (ver Fig 3.1) nem avançou para a formação de políticas públicas mais amplas para o setor. Mais tarde, com a chegada de Benvinda Levy e o memorando de entendimento, estabeleceu-se o início da fase de construção compartilhada que significou avanços importantes, mas ainda assim a ausência de políticas públicas claras para resolver problemas profundos do sistema prisional moçambicano. A seguir, discute-se um dos mecanismos como o qual o Estado impediu que a sociedade civil avançasse suas reivindicações de tal forma a sedimentar políticas públicas para o setor.

\section{POLÍTICA DE ATRASO: O MECANISMO PRINCIPAL DO PROCESSO DE NEUTRALIZAÇÃO}

Dois episódios identificam esforços de neutralização da questão prisional em Moçambique durante a intervenção da sociedade çivil até 2009. Ambos se configuraram com a aplicação de uma postura de atrasar procedimentos por parte do governo. O primeiro é do ano de 1996, quando o Ministério do Interior assinou memorando se comprometendo a aceitar que a LDH ministrasse cursos de direitos humanos a policiais. Em meados do mesmo ano, mudou de ideia, delegando ao Escritório de Investigação Criminal que ministrasse seminários de formação para agentes em "direitos humanos, aperfeiçoamento técnico e legal, mas sem o apoio da LDH". ${ }^{24} \mathrm{O}$ projeto de formação só foi colocado em prática quase 15 anos depois. A nova versão do projeto incluiu então a formação de agentes penitenciários, com financiamento de organizações internacionais. ${ }^{25}$ Já em 2006, Moçambique criou o SENARP, que deveria "fiscalizar as prisões, a gestão, a supervisão e a promoção de oportunidades de trabalho e de tarefas para os prisioneiros", (...) mas enfrentou "escassez de fundos e de recursos humanos capacitados". 26 O não-funcionamento do SERNAP nos seus dois primeiros anos marcou uma faceta do mecanismo de neutralização por uma política oficial de atrasar iniciativas.

A construção compartilhada favoreceu a ampliação do diálogo da Liga com o governo em outros temas dos direitos humanos. No entanto, os atrasos continuaram sendo implementados para neutralizar o avanço de iniciativas decivas (ver Fig.3.1 para entender como a neutralização se insere em processos de co-construção). A Comissão Nacional de Direitos Humanos (CNDH), por exemplo, foi regulamentada pelo governo em 2009, após seis anos de pleito da LDH junto ao governo. ${ }^{27}$

\footnotetext{
24 See HRW (1996)

${ }^{25}$ Entrevista Trabalhador de ONG, Nampula, 1 de maio de 2015

26 Ver Lorizzo (2012).

27 O plano estratégico da LDH no triênio 2000-2003 previa sensibilização de autoridades para fortalecer o diálogo com o governo através da criação da CNDH. Mais forte financeiramente, a organização convidou autoridades do Estado a visitarem comissões africanas que já estavam em atividade - como a comissão sul-africana e ugandesa (Entrevista Trabalhador de ONG, Maputo, 30 De outubro de 2016)
} 


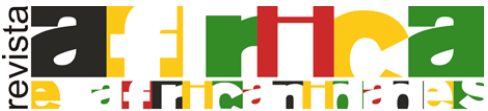

Revista África e Africanidades - Ano XIII - n. 34, maio. 2020 - ISSN 1983-2354 www.africaeafricanidades.com.br

Fig. 3 Teoria do desacato na SC - inter-relação de conceitos-chave

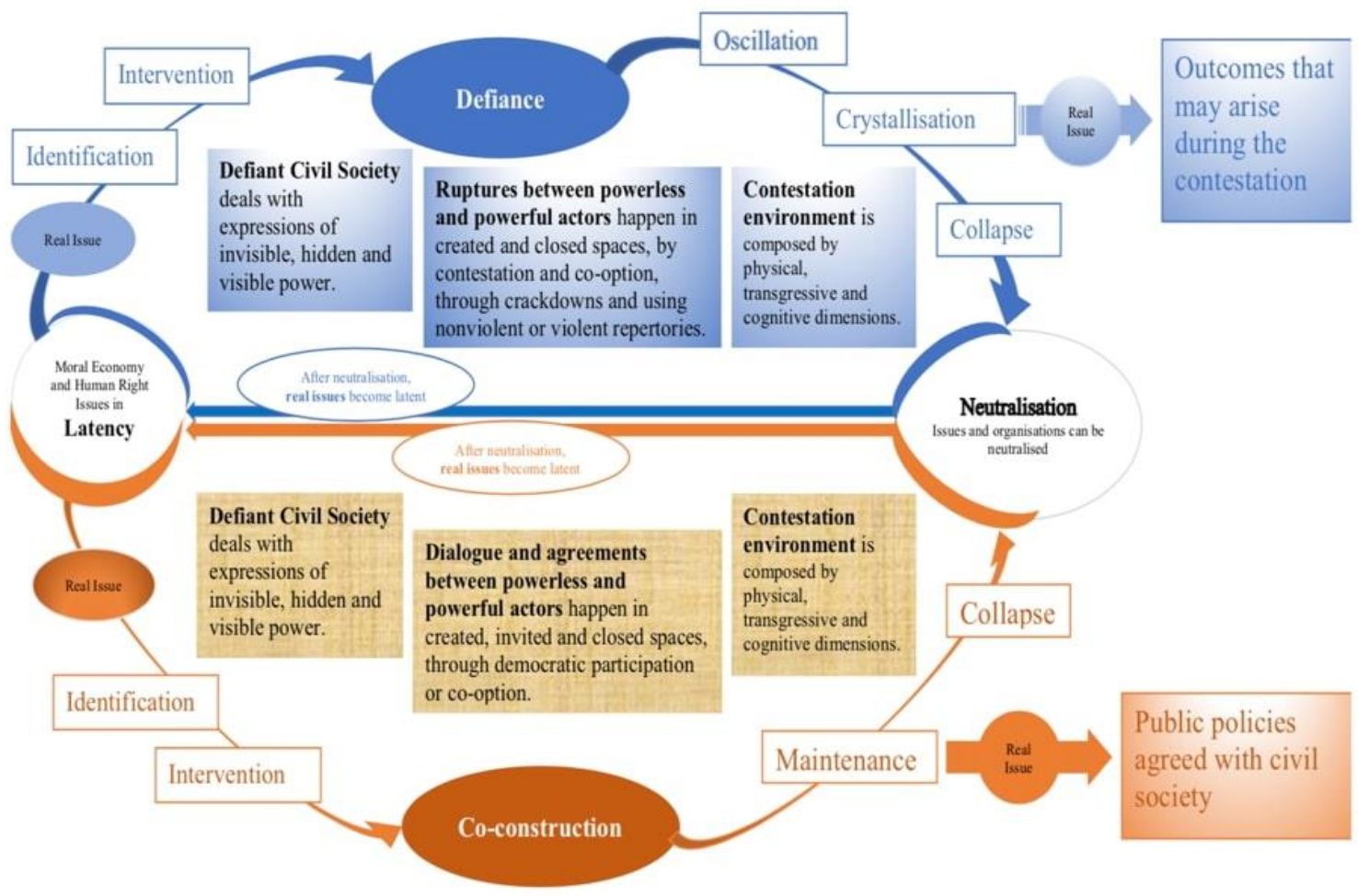

É considerada por ex-funcionários da Liga como outro marco da mudança de tom no processo de construção compartilhada entre organização e governo. Além de ser protagonista importante na constituição da comissão, a Liga teve a função de organizar a sociedade civil para escolher seus representantes neste espaço constituído por convite do Estado, ou "espaço convidado". ${ }^{28} \mathrm{CNDH}$ começou a operar em 2011. Tem hoje 10 membros indicados pelo Governo, da sociedade civil em geral e Ordem dos Advogados. A CNDH não funciona bem por falta de recursos humanos e financeiros, além de ter conflitos internos causados pela política partidária. Principalmente o vínculo de alguns de seus integrantes com o núcleo mais poderoso da FRELIMO torna complexa as relações de poder dentro destes espaços convidados. É um dos fatores que fazem com que muitos considerem que, apesar de a comissão conseguir divulgar a sua existência para a população e para o governo, funciona mal. Nos momentos que é preciso votar questões sensíveis, como assassinatos políticos, membros que acham que tem que defender os interesses do seu grupo de origem obstruem processos. "Muitos ainda não têm na cabeça que estão lá para defender os interesses da comissão, apesar de serem indicados pelas suas instituições que tem cores partidárias". ${ }^{29}$

Uma situação emblemática dos desafios enfrentados pelo CNDH pode ser notada no assassinato político do acadêmico Gillez Cistac. Como é um órgão

28 Ver Gaventa (2006)
29 Trabalhador de ONG, Maputo, 30 de outubro de 2016. 


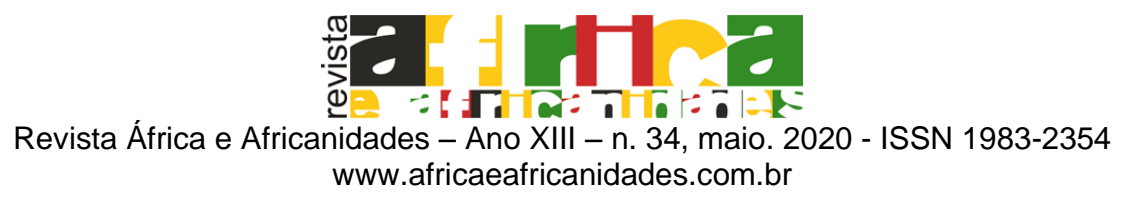

colegial, as posições institucionais precisam ter consenso, o que é difícil de ocorrer. Houve sempre uma divisão interna sobre o entendimento do Caso Cistac, porque se trata de um caso sensível para a FRELIMO e o governo. Além disso, por falta de recursos financeiros e humanos, não há como investigar paralelamente o caso. A CNDH se limitou a apelar à Procuradoria da República para fazer os procedimentos legais. Segundo um memobr da CNDH, "mesmo que fosse feita uma investigação paralela, no momento da aprovação do relatório final, haveria um problema ligado a falta de consenso sobre o teor do relatório" pela divisão política interna. ${ }^{30}$

A luta das organizações da sociedade civil para melhorar as condições dos detentos sempre foi normativa, baseada na Declaração Universal dos Direitos Humanos. Trata-se de uma postura contenciosa baseada em valores exógenos ocidentais, ou seja, com identidade frágil com grupos sociais autóctones e tradicionais africanos. Não obstante, tal postura das ONGs levou questões reais para a comunidade reclusa (detentos e familiares) à esfera pública em meio a uma série de questões normativas, vinculadas aos direitos humanos, que conseguiam dialogar com o arcabouço legal do Estado. Por outro lado, o jargão jurídico em torno dos direitos humanos é dominado por uma elite jurídica e ativista, mas é inacessível para reclusos e suas famílias inseridos em um setor mais endógeno da sociedade. Isto impede que as organizações logrem engajar a comunidade reclusa em lutas por condições melhores na prisão, e esse isolamento das ONGs é histórico. ${ }^{31} \mathrm{~A}$ seção a seguir analisa o que são questões reais e o que são questões periféricas no sistema carcerário moçambicano.

\section{QUESTÕES REAIS PARA DETENTOS E FAMILIARES}

Em Moçambique, as questões reais estão muito relacionadas a temas de economia moral porque estão vinculados a "acordos tácitos" e "expectativas" econômicas mútuas entre os envolvidos e a uma "ética de subsistência". ${ }^{32}$ Há estudos que evidenciam que questões reais são capazes de gerar processos de desacato mesmo quando tais questões não são abordadas diretamente. Esta seção mostra que, mesmo em ambientes de extrema repressão, questões reais podem levar à processos de construção compartilhada e desacato na sociedade civil, além disso podem ter conexão com o arcabouço normativo dos direitos humanos. Para isto, incialmente se busca entender quais são as expectativas morais e de subsistência que a comunidade reclusa moçambicana tem em torno do sistema prisional, e como estes grupos endógenos colocam as questões reais em destaque à revelia dos grupos exógenos que potencialmente poderiam Ihes ajudar, como ONGs locais e internacionais e agências de governos de outros países.

\footnotetext{
30 Trabalhador de ONG, Bonn, 30 de outubro de 2016.

31 Verdade (2012).

32 Ver Pessôa (2018); De Britto (2014); Sieméant (2015); Scott (1974)
} 


\section{善D \\ Revista África e Africanidades - Ano XIII - n. 34, maio. 2020 - ISSN 1983-2354 \\ www.africaeafricanidades.com.br}

O encarceramento como punição começou a ser aplicado na África austral no início do século dezenove e tinha conexão com o tráfico de escravos do Atlântico. ${ }^{33}$ As potências coloniais não usavam o encarceramento para reabilitação ou reintegração, mas para subjugar econômica, política e socialmente povos nativos. ${ }^{34}$ Mesmo leves infrações eram respondidas com confinamentos brutais, torturas, castigos corporais e trabalhos forçados. Peté and Devenish identificam que tortura e pena de morte foram legitimadas entre europeus pela caracterização dos africanos como incivilizados, infantis e selvagens ${ }^{35}$ Sarkin argumenta que, diante da gênese do sistema carcerário, não surpreende que, depois de 40 anos de libertação, as "prisões africanas não cumpram metas de reabilitação e persistam (...) abusos iniciados séculos atrás". 36

No entanto, havia diferenças cruciais no tratamento de "delinquentes" e de escravos que, segundo Capela, em alguns casos, até defendiam sua condição. ${ }^{37}$ Mesmo com a desapropriação de todos os direitos naturais da pessoa e revoltas sendo registradas pelo desterro, ${ }^{38}$ o cerceamento da liberdade através de raptos e posterior escravidão foi interpretada como "imposição de submissão" sob a condição de "subsistência", ou seja, aqui já estava presente um acordo tácito econômico. Havia uma mínima expectativa moral na relação entre escravos e senhores, onde escravos teriam acesso conveniente a recursos de subsistência, ${ }^{39}$ muito embora suas famílias de origem ficassem desassistidas. ${ }^{40}$ Os senhores, por exemplo, enviavam seus escravos para serem castigados na prisão, o que identifica o contraste evidente de expectativas entre o "escravo" e o "encarcerado para punição". 41

O aprisionamento para punição pressupunha castigo brutal sob condições sub-humanas, onde o encarcerado teria culpa pelo seu destino, uma narrativa que se reproduziu até os anos 2000 em Moçambique. ${ }^{42}$ Ainda hoje, o governo busca formas de repassar aos presos os custos da carceragem. ${ }^{43}$ Ao mesmo tempo, não resolve as condições precárias nem se oferece possibilidade de reação aos maus tratos. ${ }^{44}$

\footnotetext{
33 Ver Vansina (2003); Thomas (1999)

34 Sarkin (2008)

35 Peté and Devenish (2005)

${ }^{36}$ Sarkin (2008)

37 Capela (2000)

38 Ver Capela (2002) e Thomaz (2012)

39 Capela, 2000, p. 35

40 Thomaz (2013)

${ }^{41}$ Ver Sarkin (2008)

42 ver HRW (1998)

${ }^{43}$ Sapo (2013d)

${ }^{44}$ Pessôa (2014); Lorizzo (2012).
} 


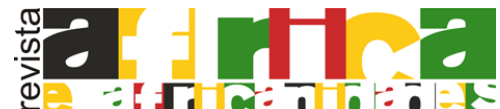

Revista África e Africanidades - Ano XIII - n. 34, maio. 2020 - ISSN 1983-2354 www.africaeafricanidades.com.br

As ONGs abriram várias frentes normativas para lidar com as condições precárias do cárcere. Falta de espaço físico, aumento da criminalidade e excesso de prisões preventivas são vistos como os eixos responsáveis pela superlotação (ver tabela 11), que, por sua vez, gera uma constelação de violações de direitos humanos.' A impressão dos ativistas das ONGs é de que as rebeliões nas penitenciárias moçambicanas são raras, apesar das condições sub-humanas. ${ }^{45} \mathrm{Em} \mathrm{2012,} \mathrm{o} \mathrm{SERNAP} \mathrm{registrou} 343$ fugas, um aumento de $16,3 \%$ em relação ao ano anterior - a maioria nas prisões de Nampula, Gaza e Tete. ${ }^{46}$ Apesar dos esforços das ONGs, não há levantamento sobre rebeliões e é impossível saber se todos os motins vão a conhecimento público.

Tabela 1: População prisional x Capacidade Física

\begin{tabular}{|c|c|c|c|c|c|c|c|c|c|}
\hline \multirow{2}{*}{ 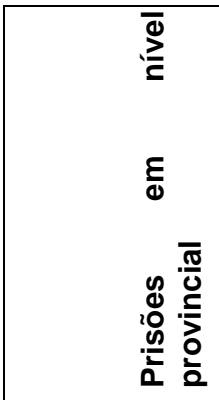 } & \multicolumn{3}{|c|}{ Ano 2012} & \multicolumn{3}{|c|}{ Ano 2013} & \multicolumn{3}{|c|}{ Ano 2014} \\
\hline & \begin{tabular}{l}
$\frac{0}{0}$ \\
$\frac{\pi}{0}$ \\
\hdashline 00 \\
$\mathbb{0}$ \\
$\frac{\mathbb{Z}}{\mathbb{J}}$ \\
0
\end{tabular} & 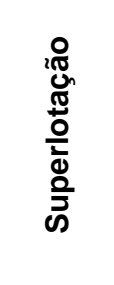 & 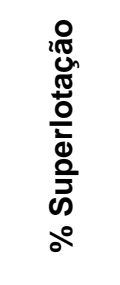 & \begin{tabular}{l}
0 \\
$\frac{0}{0}$ \\
$\frac{\pi}{0}$ \\
\hdashline 0 \\
$\mathbb{0}$ \\
$\frac{0}{\pi}$ \\
0
\end{tabular} & 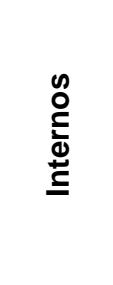 & 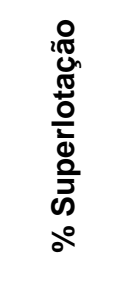 & \begin{tabular}{l}
$\frac{0}{0}$ \\
$\frac{\pi}{0}$ \\
\hdashline 00 \\
$\mathbb{0}$ \\
$\frac{\mathbb{Z}}{\mathbb{J}}$
\end{tabular} & 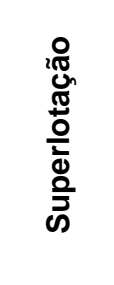 & 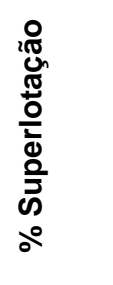 \\
\hline NIASSA & 150 & 686 & 357.33 & 150 & 660 & 340.00 & 150 & 661 & 340.67 \\
\hline $\begin{array}{l}\text { CABO } \\
\text { DELGADO }\end{array}$ & 495 & 934 & 88.69 & 495 & 834 & 68.48 & 495 & 791 & 59.80 \\
\hline NAMPULA & 1527 & 2975 & 94.83 & 1527 & 2714 & 77.73 & 1527 & 2664 & 74.46 \\
\hline ZAMBÉZIA & 375 & 1441 & 284.27 & 375 & 1369 & 265.07 & 375 & 1439 & 283.73 \\
\hline TETE & 340 & 1046 & 207.65 & 340 & 1086 & 219.41 & 340 & 989 & 190.88 \\
\hline MANICA & 985 & 1655 & 68.02 & 985 & 1406 & 42.74 & 985 & 1542 & 56.55 \\
\hline SOFALA & 285 & 1329 & 366.32 & 285 & 1352 & 374.39 & 285 & 1318 & 362.46 \\
\hline INHAMBANE & 350 & 1035 & 195.71 & 470 & 992 & 111.06 & 470 & 975 & 107.45 \\
\hline GAZA & 1115 & 1424 & 27.71 & 1115 & 1264 & 13.36 & 1115 & 1298 & 16.41 \\
\hline MAPUTO & 2182 & 3354 & 53.71 & 2182 & 3450 & 58.11 & 2182 & 3294 & 50.96 \\
\hline TOTAL & 7,804 & 15,879 & 103.47 & 7,924 & 15,127 & 90.90 & 7,924 & 14,971 & 88.93 \\
\hline
\end{tabular}

Fonte: $\mathrm{CDH}$ and LDH 2015

\footnotetext{
${ }^{45}$ Entrevista Trabalhador de ONG, Quelimane, 8 de maio de 2015 and CDH e LDH 2015

46 Entrevista Trabalhador de ONG, Quelimane, 8 de maio de 2015; Entrevista Trabalhador de ONG, Maputo, 7 de dezembro de2014; Entrevista Trabalhador de ONG, Nampula, 1 de maio de 2015; Entrevista Trabalhador de ONG, Maputo, 4 de dezembro de2014
} 


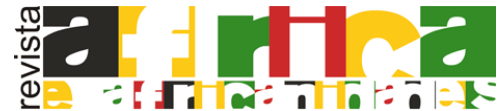

Revista África e Africanidades - Ano XIII - n. 34, maio. 2020 - ISSN 1983-2354 www.africaeafricanidades.com.br

A prisão faz com que o detento fique impossibilitado de garantir a sua própria subsistência. Além disso, sua família sofre impactos econômicos pela sua detenção. ${ }^{47}$

'Mais de $90 \%$ dos reclusos em Moçambique têm algum nível de escolaridade, sendo que $7 \%$ não frequentaram a escola enquanto $2 \%$ tem ensino superior. Mais da metade diz não estar habilitado em uma profissão, e as ocupações mais frequentes são: camponês, mecânico, pedreiro, empregado doméstico, vigilante, estudante, motorista e negociante. ${ }^{48}$

A prisão preventiva em Moçambique, por exemplo, contribui para o empobrecimento e a vulnerabilidade das famílias, uma vez que $72 \%$ dos presos preventivos são economicamente ativos com renda média próxima ao salário mínimo (MT 3.600,00), 92\% apoiava suas crianças ou outros dependentes, e $70 \%$ garantiam a renda familiar antes de serem encarcerados. Quase $70 \%$ das famílias relataram perda de renda. ${ }^{49}$

'A detenção de membros do agregado familiar traz custos novos, diretos e não planejados para a família: as visitas estão associadas a custos, tais como transporte para a visita, alimentação, outros materiais (por exemplo, sabão, vestuário, medicamentos e assim por diante). Assegurar assistência jurídica privada - ou tentar fazê-lo - ou assistência de uma instituição estatal (por exemplo, Comissão de Direitos Humanos) também pode resultar em custos. Recolher dinheiro para pagar a fiança, pedir dinheiro emprestado, usar poupanças ou pagar um suborno são custos adicionais associados à detenção. O tempo também é gasto em visitas e não em outras atividades produtivas. Portanto, a prisão preventiva não se trata apenas de perder contribuições financeiras e não financeiras, mas também de incorrer em despesas novas e não planejadas. Presumivelmente, quanto mais tempo a detenção continuar, maior será o total dessas despesas - até que a família seja forçada a deixar de incorrer nessas despesas para sobreviver. ${ }^{150}$

Portanto, a prisão é cara para a "comunidade reclusa", mas não há registro de protestos reivindicatórias sobre este tema tanto por parte das famílias quanto por parte dos internos. Ou seja, é um tema das ONGs e do meio acadêmico.

Tabela 2 Demonstração evolutiva gráfica da situação jurídico-legal da população em reclusão

\footnotetext{
47 Pessôa et al. (2016)

${ }^{48} \mathrm{CDH}$ e LDH, 2015, p.57

${ }^{49}$ See Muntingh and Redpath (2017)

${ }^{50}$ Muntingh and Redpath, 2017, p.10
} 


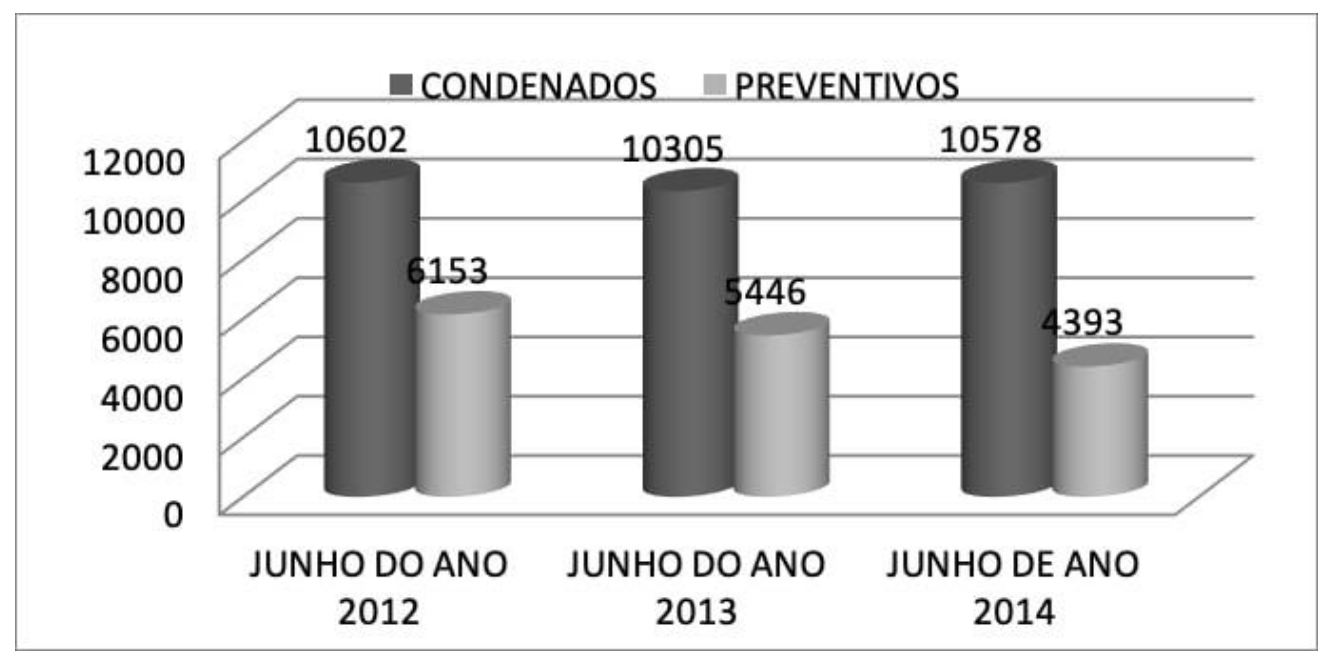

Fonte: (CDH e LDH, 2015).

Levantamento da LDH feito em 2013, por exemplo, constatou que o número de "preventivos aguardando julgamentos" fora do prazo legal aumentou quase $70 \%$ em relação ao ano anterior. ${ }^{51}$ Até $35 \%$ da capacidade prisional moçambicana era ocupada por reclusos em prisão preventiva e "a grande maioria nem sabe a situação do seu processo". ${ }^{52}$ Dos 12.763 casos de presos observados pelos pesquisadores, 568 não tinham assistência jurídica em $2012 .{ }^{53}$ Em 2014, o número de reclusos sem assistência jurídica nos estabelecimentos prisionais aumentou $28,1 \%$ em relação a 2012. Com a aplicação de medidas alternativas e avaliação das prisões preventivas expiradas, o governo calcula que $37 \%$ dos detentos estariam fora da prisão. ${ }^{54}$

Apesar da dedicação dos setores exógenos da sociedade civil em combater a superlotação e o cárcere ilegal - uma vez que há prisões preventivas expiradas - processos de desacato da massa carcerária têm outras razões específicas para ocorrer. Entre 17 episódios que vieram a público relacionados a rebeliões, reclamações de detentos e familiares, iniciativas governamentais ou não governamentais - entre janeiro de 2010 e dezembro de 2016 - mais da metade tem a ver com a alimentação (ver tabela 12). Há motins relacionados à reação de detentos à violência durante revista das celas em Maputo; há fugas em massa e depredação relacionadas á superlotação, mas mal esclarecidas, especialmente na Cadeia de Nampula, província que tem duas penitenciárias uma precária e superlotada e outra em excelentes condições; ${ }^{55}$ há episódios que envolvem somente detentos (sem familiares), de caráter não-reivindicatório como protesto por mortes e por apreensões de telefones celulares. ${ }^{56}$

\footnotetext{
51 Pessôa et al. (2014)

52 Entrevista Trabalhador de ONG, Maputo, 14 de dezembro de2014

$53 \mathrm{CDH}$ e LDH (2014)

54 Jornal A Bola (2017)

55 VOA (2011); Radio Moçambique (2012); OPaís (2014)

56 Jornal Notícias (2016); Infodiário (2015)
} 
No entanto, observa-se que episódios que afetam detentos e familiares simultaneamente podem gerar protestos dentro e fora da prisão. A food riot de $2010,{ }^{57}$ por exemplo, que afetou familiares de centenas de detentos, gerou protestos dentro de uma penitenciária em Maputo, quando eles exigiam voltar para às ruas onde setores exógenos se rebelaram. ${ }^{58}$

Tabela 3: Episódios e motins na imprensa de janeiro de 2010 e dezembro de 2016

\begin{tabular}{|c|c|c|}
\hline Data & $\begin{array}{l}\text { Estabelecimento } \\
\text { Prisional }\end{array}$ & Episódio \\
\hline 02.02 .2010 & $\begin{array}{l}\text { Cadeia Central da } \\
\text { Machava }\end{array}$ & $\begin{array}{l}\text { Rebelião teve jovem baleado pela FIR. Ocorria as } \\
\text { manifestações do pão e do chapa. "Queriam ir } \\
\text { para casa". }\end{array}$ \\
\hline 09.12 .2010 & $\begin{array}{l}\text { Cadeia Feminina de } \\
\text { Ndlavela }\end{array}$ & $\begin{array}{l}\text { Inaugura projeto com doação da Dinamarca para } \\
\text { criação de frangos para reduzir dependência do } \\
\text { governo. }\end{array}$ \\
\hline 04.04 .2011 & $\begin{array}{l}\text { Cadeia Provincial de } \\
\text { Nampula }\end{array}$ & $\begin{array}{l}\text { Motim "contra a superlotação, higiene e } \\
\text { saneamento". Espaço para } 90 \text { presos, estava } \\
\text { com mais de } 550 \text {. Transferidos para a industrial } \\
\text { de Nampula. }\end{array}$ \\
\hline 16.07 .2011 & $\begin{array}{l}\text { Cadeia Provincial de } \\
\text { Nampula }\end{array}$ & $\begin{array}{l}\text { Familiares proibidos de fornecer refeição aos } \\
\text { parentes exigiram explicações. Direção há dias } \\
\text { proibia a entrada de alimentos sem motivo } \\
\text { revelado. }\end{array}$ \\
\hline 14.09 .2011 & $\begin{array}{l}\text { Motim Cabeça e Velho } \\
\text { Chimoio (Manica) }\end{array}$ & $\begin{array}{l}\text { Quase } 90 \text { reclusos se rebelaram alegando } \\
\text { "deficiência na dieta alimentar". "Uma circular na } \\
\text { semana anterior proibia entrada de alimentos de } \\
\text { fora". }\end{array}$ \\
\hline 12.03 .2012 & $\begin{array}{l}\text { Cadeia Provincial de } \\
\text { Nampula }\end{array}$ & $\begin{array}{l}\text { Rebelião com depredação de celas. "Presos } \\
\text { queriam sair juntos para o banho de sol". } 194 \\
\text { reclusos transferidos à Penitenciária Industrial de } \\
\text { Nampula. }\end{array}$ \\
\hline 07.11 .2012 & $\begin{array}{l}\text { Cadeia de Máxima } \\
\text { Segurança de Maputo BO }\end{array}$ & $\begin{array}{l}\text { Presos fazem greve de fome. "SERNAP informou } \\
\text { que a rebelião foi causada pelas buscas a } \\
\text { telemóveis e droga". Havia } 864 \text { reclusos, } 440 \\
\text { cumprem pena e } 424 \text { aguardam julgamento. }\end{array}$ \\
\hline 20.11 .2012 & Cadeia de Tete & Fuga de 46 após motim. \\
\hline 24.05 .2013 & $\begin{array}{l}\text { Cabeça e Velho Chimoio } \\
\text { (Manica) }\end{array}$ & $\begin{array}{l}\text { SERNAP anuncia que reclusos vão cultivar hortas } \\
\text { para o próprio sustento "para reduzir gastos do } \\
\text { governo com comida. Atividades econômicas } \\
\text { cobrem } 14 \% \text { das necessidades". }\end{array}$ \\
\hline
\end{tabular}

57 De Brito et al. (2014)

58 Sapo (2010) 


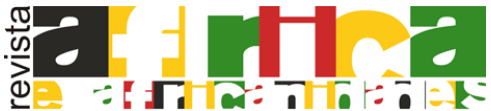

Revista África e Africanidades - Ano XIII - n. 34, maio. 2020 - ISSN 1983-2354 www.africaeafricanidades.com.br

\begin{tabular}{|c|c|c|}
\hline 19.02.2014 & $\begin{array}{l}\text { Centro Penitenciário de } \\
\text { Mieze e Cadeia provincial } \\
\text { de Pemba (Cabo } \\
\text { Delgado) }\end{array}$ & $\begin{array}{l}\text { Familiares querem processar ministra pela morta } \\
\text { de } 16 \text { detentos alegadamente de fome. Três } \\
\text { morreram de anemia em outra cadeia meses } \\
\text { antes. }\end{array}$ \\
\hline 04.04 .2014 & $\begin{array}{l}\text { Estabelecimento } \\
\text { Penitenciário Preventivo } \\
\text { de Maputo }\end{array}$ & $\begin{array}{l}\text { Rebelião por recusa de liberdade condicional a } \\
\text { uma detenta brasileira. }\end{array}$ \\
\hline 16.07.2014 & $\begin{array}{l}\text { Cadeia Central da } \\
\text { Machava }\end{array}$ & $\begin{array}{l}\text { Detentos de Würzburg doam uma saca de } \\
\text { açúcar, arroz e sabão para cada detento da } \\
\text { Machava. }\end{array}$ \\
\hline 25.04 .2015 & $\begin{array}{l}\text { Cadeia de Máxima } \\
\text { Segurança BO }\end{array}$ & $\begin{array}{l}\text { "Detentos querem cozinhar ao invés de receber } \\
\text { alimentos prontos da família. }\end{array}$ \\
\hline 05.10 .2015 & $\begin{array}{l}\text { Cadeia Central da } \\
\text { Machava }\end{array}$ & Motim devido à "morte de recluso no hospital". \\
\hline 30.03 .2016 & $\begin{array}{l}\text { Penitenciária Regional de } \\
\text { mabalane (Gaza) }\end{array}$ & $\begin{array}{l}\text { Reclusos denunciam alimentação precária. "Casa } \\
\text { revela baixo orçamento para comida". }\end{array}$ \\
\hline 14.12.2016 & $\begin{array}{l}\text { Cadeia Central da } \\
\text { Machava }\end{array}$ & $\begin{array}{l}\text { Motim após "busca e apreensão". Serviço de } \\
\text { Inteligência das Prisões. }\end{array}$ \\
\hline
\end{tabular}

Fonte: Levantamento junto à imprensa moçambicana (jornais citados na bibliografia)

A alimentação precária ou inexistente gera reivindicações e iniciativas públicas, privadas e de doadores para provisão, ${ }^{59}$ mas o bloqueio do ingresso de alimentos dados pelas famílias gera desobediência coletiva, protestos ou rebelião de caráter reivindicatório dentro e fora da prisão. ${ }^{60}$ Já se sabe que a superlotação dificulta a administração da qualidade ou da quantidade dos alimentos e o Estado está ciente que não é capaz de (ou não quer) arcar com o fornecimento de alimentos com orçamentos fixos e população carcerária em crescimento. ${ }^{61}$ Por isto abre a possibilidade dos familiares ajudarem os reclusos nas cadeias. ${ }^{62}$

A obstrução da entrega de alimentos da família parece ser uma questão tão sensível, que gera rebelião não somente dos detentos, mas também de seus familiares. Para os setores endógenos, a proibição da entrada de ajuda extrapola os limites históricos dos maus tratos que marcam a restrição de liberdade punitiva em Moçambique. A obstrução do fluxo da comida é um tema tão

59 Sapo (2013c); Sapo (2013d); Comunità di Sant' Egidio (2014); CanalMoz (2014)

60 Entrevista Trabalhador de ONG, Maputo, 14 de dezembro de 2014; Entrevista Trabalhador de ONG, Maputo, 7 de dezembro de2014; Entrevista Trabalhador de ONG, Quelimane, 08 de maio de 2015; Sapo (2011b); Sapo (2015); Sapo (2011a)

${ }^{61}$ Entrevista Trabalhador de ONG, Maputo, 14 de dezembro de2014;

62 Entrevista Trabalhador de ONG, Maputo, 4 de dezembro de2014 


\section{$\sum_{0}^{\frac{\pi}{0}} 0$ \\ Revista África e Africanidades - Ano XIII - n. 34, maio. 2020 - ISSN 1983-2354 www.africaeafricanidades.com.br}

inflamável que pode gerar rebelião em penitenciárias onde a questão da superlotação não é dramática. ${ }^{63}$

Em algumas esquadras não há comida, algumas penitenciárias fornecem uma refeição por dia sem variação de cardápio ou frutas, por isso as visitas são fundamentais para a sobrevivência do detento e de outros desassistidos na mesma cela. ${ }^{64} \mathrm{O}$ cárcere lhes tira a possibilidade de "subsistência independente" por isso a massa carcerária tem a constante expectativa de que a visita possa garantir ou complementar a alimentação precária ou inexistente. O caráter moral da questão real é nítida nesta denuncia da parente de um preso na cadeia do Comando da PRM de Maputo, que estava superlotada na ocasião. Ela fala à emissora de TVM sem mostrar o rosto. O fluxo de comida para dentro foi proibido por alguns dias em janeiro de 2014:

'Não receber comida é muito difícil de aceitar. Por mais que tenham feito alguma coisa de errado, que não Ihes tirassem a refeição. Tudo o que a gente quer é simplesmente que eles tenham suas refeições. (...) O único prato que deve entrar é do Anibalzinho,65 e os outros? Será que isto não pode criar problemas lá dentro? Vamos imaginar que eles, que não recebem refeições, se reúnam... não vão gostar de saber disto. Para começar, isto não é ético. Saber que um tem direito de comer e os outros não. Meu Deus, onde nós estamos? Para onde isto vai nos levar?'.66

O histórico de maus tratos relacionados ao cárcere para punição faz familiares e detentos não terem expectativa de bom tratamento no sistema prisional. No entanto, existe uma questão de economia moral que envolve a expectativa de o Estado permitir que o recluso seja assistido pela sua família, uma vez que ele próprio não pode prover a sua subsistência. Não interessa se os detentos não estão recebendo comida por medida arbitrária disciplinar, quando a comida externa não chega às mãos do detento, ocorre a quebra desta expectativa e o risco de revolta dos presos aumenta. O Estado não provê, mas permite o acesso da assistência familiar, e este é um acordo tácito. É possível perceber um pacto não-declarado, criado por mensagens indiretas, costumes e comportamentos culturais que geram expectativas de ambas as partes quanto ao ingresso desse auxílio econômico-alimentício.

\section{CONCLUSÃO}

A sociedade civil, através da LDH, ateve-se a questões amplas e periférico-normativas e levou 16 anos para chegar ao processo de construção compartilhada com o Estado no sistema prisional. Mesmo com os acordos com - Estado, houve a manutenção de um padrão de diálogo que não foi capaz de avançar para políticas públicas profundas, consistentes e sustentáveis para 0

\footnotetext{
${ }^{63}$ Ver Sapo (2011a; 2012a; 2012b)

${ }^{64}$ Entrevista Trabalhador de ONG, Maputo, 4 de dezembro de2014; DW Africa (2012a); CDH e LDH (2014)
}

${ }^{65}$ Anibalzinho é conenado a 30 anos de prisão pela morte de Carlos Cardoso, é como uma estrela do sistema penal moçambicano.

$66 \operatorname{Tim}(2015)$ 


\section{$\sum_{0}^{\frac{\pi}{0}} 0$ \\ Revista África e Africanidades - Ano XIII - n. 34, maio. 2020 - ISSN 1983-2354 \\ www.africaeafricanidades.com.br}

setor. Uma abordagem de foco exclusivo às questões reais para os detentos moçambicanos e suas famílias, como alimentação/subsistência, nunca foi explorada.

Por outro lado, ao se ater aos direitos humanos, a sociedade civil fez intervenção indireta nessas questões reais, abordando vários temas relacionados à superlotação e aos direitos do detento - o que inclui o direito à alimentação. Mesmo assim, questões que afetam a subsistência das famílias, como um mutirão para observar prisões expiradas, não foram observadas com o devido cuidado. A realidade das rebeliões da "comunidade reclusa" - ou seja, famílias e detentos - leva a crer que todas as questões em torno do tema "alimentação/subsistência" deveriam ser levadas em consideração prioritariamente, porque se trata de uma demanda endógena. É este o tema real que pode levar a processos de desacato, ou seja, movimentos de contestação e extrema pressão que envolva a polarização da civil polarizada com o Estado.

Os direitos humanos em geral acabam sendo um tema da sociedade civil exógena à "comunidade reclusa", que inegavelmente têm gerado frutos positivos desde os anos 1990, mudando a visão do Estado sobre a massa carcerária, mas não foram capazes de impulsionar políticas públicas sustentáveis para o setor. A abordagem não resolveu questões básicas de sobrevivência dos presos e de suas famílias. Uma ação coordenada entre os setores exógenos e endógenos para um processo de desacato - onde ações contundentes de contestação promovidas por detentos e suas famílias com o apoio das ONGs possam conduzir a mudanças reais para a "comunidade reclusa" através de uma política pública para o sistema prisional - não foi pensada. A LDH sempre foi um agente exógeno da sociedade civil que viu a "comunidade reclusa" [os interessados endógenos] como cliente para o quais deveria prestar assistência jurídica. As ONGs não têm um foco primordial na subsistência da família e do detento e sim nas causas e efeitos da superlotação para os direitos humanos de forma ampla. Isto acaba não gerando tal engajamento conjunto para um processo de desacato, que seria capaz de produzir uma dinâmica de pressão popular jamais vista no setor para uma política pública sustentável formulada e implementada por sociedade civil e Estado.

\section{BIBLIOGRAFIA}

CAPELA, José. Escravos e escravatura em Moçambique: problemas identitários. Revista Africana Studia. V.3, 2000, 33-48. 


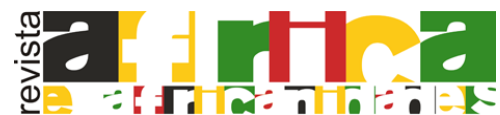

Revista África e Africanidades - Ano XIII - n. 34, maio. 2020 - ISSN 1983-2354 www.africaeafricanidades.com.br

CAPELA, José. O Tráfico de Escravos nos Portos de Moçambique, 1733-1904, Porto: Afrontamento, 2002.

CDH e LDH. Privação da Liberdade antes do julgamento no ordenamento jurídico moçambicano - Avaliação do Regime Legal e das Práticas por Referência aos Padrões Internacionais. Maputo: CDH, 2015. (Draft)

DE BRITO, Luís, CHAIMITE, Egídio, PEREIRA, Crescêncio, POSSE, Lúcio, SAMBO, Michael and SHANKLAND, Alex. (2014), Hunger Revolts and Citizen Strikes: Popular Protests in Mozambique, 2008-2012, Food Riots and Food Rights project report, Brighton/Maputo: IDS/IESE. www.foodriots.org (Acessado em 21 de outubro de 2015).

GAVENTA, John. Finding the Spaces for Change: A Power Analysis. IDS Bulletin. V.37, April/2006, 23-33.

HABERMAS, Jürgen. Faktizität und Geltung. Beiträge zur Diskurstheorie des Rechts und des demokratischen Rechtsstaats. 2nd ed. Frankfurt am Main: Suhrkamp. Jürgen, 1992.

LANG, Sabine. NGOs, Civil Society, and the Public Sphere, New York: Cambridge University Press, 2013.

LORIZZO, Tina. Prison Reforms in Mozambique fail to touch the ground: assessing the experience of pre-trial detainees in Maputo. Crime Quaterly, V.42, 08/03/2012, 29-38.

MUNTINGH, Lukas and REDPATH, Jean. The socio-economic impact of pre-trial detention in Kenya, Mozambique and Zambia. Hague Journal of the Rule of Law. V.10, 04/2018, 139-164.

PESSÔA, Marcio; COMO, Jorge, FREITAS, Diocliciano, MANHIÇA, Stella, NOUCK, Loundry e VARIMELLO, Arquimedes. Relatório Nacional dos Direitos Humanos em Moçambique 2013-2014, Maputo: LDH, 2014. (draft)

PESSÔA, Marcio; COMO, Jorge, FREITAS, Diocliciano. Tráfico de Órgãos e Partes do Corpo Humano - Um crime organizado aos olhos do Estado (2010-2014). Maputo: LDH, 2016.

PESSÔA, Marcio. Defiant Civil Society: Power and Contestation in Mozambique, $\mathrm{PhD}$ dissertation. IDS/University of Sussex, Brighton, 2018.

PETÉ, Stephen. and DEVENISH, Annie. Flogging, Fear and Food: Punishment and Race in Colonial Natal. Journal of Southern African Studies. V.31, 03/2005, 3-21.

SARKIN, Jeremy. Prisões na África: uma avaliação da perspectiva dos direitos humanos. Sur, Revista Internacional de Direitos Humanos. V.5, 2008, 23-51

SCOTT, James. The Moral Economy of the Peasant: Rebellion and Subsistence in Southeast Asia, London: Yale University Press, 1976.

SIMÉANT, Johanna. Three bodies of moral economy: the diffusion of a concept, Journal of Global Ethics. V.11, 29/07/2015, 163-175.

THOMAS, Hug. The slave trade: The story of the Atlantic Slave Trade: 1440-1870. New York: Touchstone, 1999.

THOMAZ, Fernanda do Nascimento. Alguns apontamentos sobre penhor humano, rapto e escravização no norte de Moçambique entre o final do século XIX e início de XX. SYNTHESIS. V.5, 2012, 183-195.

TILLY, Chares. and TARROW, Sidney. Contentious Politics, $2^{\text {nd }} \mathrm{Ed}$, Oxford: Oxford Press, 2015. (Kindle edition). 


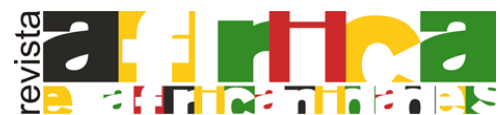

Revista África e Africanidades - Ano XIII - n. 34, maio. 2020 - ISSN 1983-2354 www.africaeafricanidades.com.br

VANSINA, Jan. Confinment in Angola's past. BERNAULT, Florence. (org). A history of prison and confinement in Africa. Heinemann: Portsmouth, 2003. (55-68)

Fontes online

CANALMOZ (2014) Familiares de reclusos que morreram de fome avançam queixacrime contra Benvinda Levi, 19 February,

http://macua.blogs.com/moambique_para_todos/2014/02/familiares-de-reclusos-quemorreram-de-fome-avan\%C3\%A7am-queixa-crime-contra-benvinda-levi.html (acessado em 29 de novembro de 2016)

COMUNITÀ DI SANT'EGIDIO (2014) Moçambique: Distribuição de alimentos na cadeia de máxima segurança de Machava, 19 July,

http://dream.santegidio.org/2014/07/19/pt1283/?lang=pt-br (acessado em 29 de novembro de 2016)

CRM (2004), "Constituição da República de Moçambique", available at: http://tiny.cc/etqm4y (acessado em 5 de outubro de 2017)

DIÁRIO DE NOTÍCIAS (2017) Cadeias moçambicanas com 11.800 reclusos acima da capacidade, 20 July, http://www.dn.pt/lusa/interior/cadeias-mocambicanas-com-11800reclusos-acima-da-capacidade-8650531.html (acessado em 23 de julho de 2017)

DW AFRICA (2012a) Violação dos direitos humanos dos reclusos em Moçambique, 22 Novembro, www.dw.com/pt-002/viola\%C3\%A7\%C3\%A3o-dos-direitos-humanos-dosreclusos-em-mo\%C3\%A7ambique/a-16398762 (acessado em 20 de julho de 2017).

HRW (1996) Human Rights Watch report about Human Rights in Mozambique, www.hrw.org/reports/1997/WR97/AFRICA-06.htm\#TopOfPag (acessado em 11 de outubro de 2015)

HRW (1997) Human Rights Watch report about Human Rights in Mozambique, www.hrw.org/reports/1997/WR97/AFRICA-06.htm\#TopOfPage (acessado em 11 de outubro de 2015)

HRW (1998) Human Rights Watch report about Human Rights in Mozambique, www.refworld.org/category,COI,HRW,,MOZ,3ae6a8b010,0.html (acessado em 11 de outubro de 2015)

HRW (1999) Human Rights Watch report about Human Rights in Mozambique, www.hrw.org/legacy/worldreport99/africa/mozambique3.html (acessado em $11 \mathrm{de}$ outubro de 2015).

HRW (2000) Human Rights Watch report about Human Rights in Mozambique, www.refworld.org/docid/3ae6a8cb30.html (acessado em 11 de outubro de 2015)

INFODIÁRIO (2015) Morte de recluso gera motim na Cadeia de Máxima Segurança, 25 April, http://197.218.5.28/articles/detail_article/3867 (acessado em 12 de dezembro de 2016).

Jornal A Bola (2017) Cadeias moçambicanas com 11.800 reclusos acima da capacidade, 20 July, www.abola.pt/africa/ver.aspx?id=683347 (acessado em 20 de julho de 2017)

JORNAL DE NOTÍCIAS (2016), 6.3.2016, https://www.jn.pt/mundo/palops/interior/mocambique-tem-sete-rotas-de-trafico-deorgaos-humanos-5061091.html (acessado em 26 de novembro de 2016). 


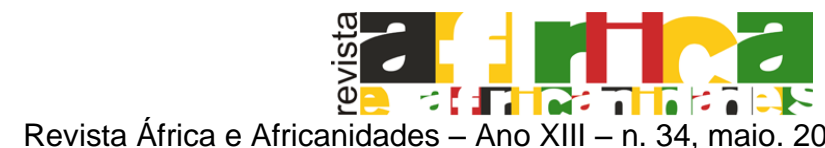

Revista África e Africanidades - Ano XIII - n. 34, maio. 2020 - ISSN 1983-2354 www.africaeafricanidades.com.br

JORNAL NOTÍCIAS (2016) Buscas terminam em motim, 14 December, http://jornalnoticias.co.mz/index.php/capital/63809-maputo-buscas-terminam-emmotim-na-penitenciaria-de-maputo.html (acessado em 12 de dezembro de 2016).

ODAMOZ (2011) Official Development Assistance to Mozambique Database, http://www.odamoz.org.mz/projects/494463 (acessado em 4 de março de 2017).

OPAís (2014) Motim de reclusas obriga cadeia reforçar segurança, 04 April, http://opais.sapo.mz/index.php/sociedade/45-sociedade/29260-motim-de-reclusasobriga-cadeia-a-reforcar-seguranca.html (acessado em 12 de dezembro de 2016)

RADIO MOÇAMBIQUE (2012) Repugnante actuação da polícia na cadeia de Nampula, 12 March, www.rm.co.mz/index.php/programacao/88-arquivo/886repugnante-actuacao-da-policia-na-cadeia-de-nampula-ministerio-da-justica.html (acessado em 26 de novembro de 2016)

SAPO (2010) Motim na cadeia central da Machava, em Moçambique, faz um morto, 2 September, http://sicnoticias.sapo.pt/mundo/2010-09-02-motim-na-cadeia-central-damachava-em-mocambique-faz-um-morto (acessado em 12 de dezembro de 2016).

SAPO (2011a) Termina motim em cadeia mas mantém-se proibição de entrada de alimentos, 14 September, http://noticias.sapo.mz/lusa/artigo/13054697.html (acessado em 12 de dezembro de 2016).

SAPO (2011b) Familiares de reclusos amotinam-se na cadeia provincial de Nampula, 18 July, http://noticias.sapo.mz/aim/artigo/171616072011145120.html (acessado em 12 de dezembro de 2016).

SAPO (2012a) Reclusos da cadeia de segurança máxima de Maputo em greve de fome, 7 November, http://noticias.sapo.mz/lusa/artigo/15262556.html (acessado em 10 de dezembro de 2016)

SAPO (2012b) Quarenta e seis reclusos evadem-se em cadeia de Tete, 20 November, http://noticiasmocambique.blogs.sapo.mz/94146.html (acessado em 12 de dezembro de 2016)

SAPO (2013c) Reclusos da Penitenciária regional de Mabalane clamam por melhor dieta alimentar, 30 May, http://opais.sapo.mz/index.php/sociedade/45-

sociedade/40138-reclusos-da-penitenciaria-regional-de-mabalane-clamam-por-melhordieta-alimentar.html (acessado em 02 de dezembro de 2016)

SAPO (2013d) Moçambique quer pôr reclusos a cultivar os seus próprios alimentos em hortas, 24 May, http://noticias.sapo.ao/lusa/artigo/16180294.html (acessado em 26 de novembro de 2016)

SAPO (2015) Reclusos vandalizam cadeia de máxima segurança, 25 April, http://noticias.sapo.mz/aim/artigo/10620225042015123318.html (acessado em 13 de dezembro de 2016).

THOMAZ, Omar .R. (2013) Seminário Nacional Interlocuções Brasil África: O tempo e o medo: diálogos surdos e a luta por direitos em Moçambique, 12 November, www.youtube.com/watch?v=vzg4uXjFmM0 (acessado em 24 de dezembro de 2015)

Tim (2015) Presos sem refeições, 13 January, http://videos.sapo.mz/gHiOYAWcq17KvR3r9OJM (acessado em 20 de julho de 2017).

U.S.D.S (2010) Human rights report: Mozambique, www.state.gov/j/drl/rls/hrrpt/2010/af/154360.htm (acessado em 29 de setembro de 2013) 


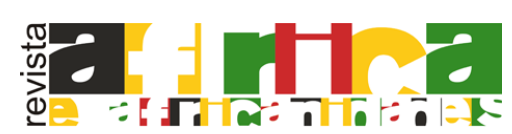

Revista África e Africanidades - Ano XIII - n. 34, maio. 2020 - ISSN 1983-2354 www.africaeafricanidades.com.br

VERDADE (2012) Entrevista Alice Mabota, 27 September, https://www.youtube.com/watch?v=NYNnzW6-c3Qandt=357s (accessed 13 May 2015)

VERDADE (2016) Presidente Nyusi empossa presidente do Conselho Constitucional que legitimou a sua eleição e também o empossou, 25 July,

http://www.verdade.co.mz/tema-de-fundo/35-themadefundo/58669-presidente-nyusiempossa-presidente-do-conselho-constitucional-que-legitimou-a-sua-eleicao-etambem-o-empossou (acessado em 02 de novembro de 2016).

VOA (2011) Superlotação na cadeia de Nampula provoca motim, 04 April, https://www.voaportugues.com/a/article-04-04-2011-mozambique-nampula-riots119239674/1259941.html (acessado em 26 de novembro de 2016) 